\title{
Pengaruh Kombinasi Ekstrak Etanolik Temulawak (Curcuma canthorrizha Roxb) Rendah Minyak Atsiri dan Ekstrak Etanolik Sambung Nyawa (Gynura procumbens (Lour.) Merr) Terhadap Kadar Trigliserida Tikus Putih Jantan Galur Wistar Serta Gambaran Histopatologinya
}

\section{Combination Effect from ethanolic extract of Curcuma (Curcuma canthorrizha Roxb) Low Essential Oils and ethanolic extract of Sambung Nyawa (Gynura procumbens (Lour.) Merr) for Triglyceride Levels Of White Male Mice Wistar strain And the Histopatology Preview}

\section{Agil Novianto*}

*)Fakultas Farmasi Universitas Gadjah Mada

*) Sekip Utara Sleman Yogyakarta Indonesia 55281; agiel.novianto@gmail.com

\begin{abstract}
INTISARI
Hiperlipidemi merupakan faktor pencetus terjadinya jantung korner dengan parameter tingginya kadar kolesterol (hiperkolesterolemia) atau trigliserida (hipertrigliserida). Penelitian dilakukan untuk mengetahui pengaruh kombinasi ekstrak etanolik temulawak (Curcuma xanthorrizha Roxb) rendah minyak atsiri dan ekstrak etanolik sambung nyawa (Gynura procumbens (Lour.) Merr) terhadap kadar trigliserida serta manifestasi hiperlipidemi berupa aterosklerosis. Sebanyak 48 hewan uji dibagi dalam 8 kelompok. Kelompok normal, kontrol positif (gemfibrozil), kontrol negatif CMC$\mathrm{Na} 0,5 \%$, dan kombinasi temulawak sambung nyawa dengan perbandingan 100:0, 75:25, 50:50, 25:75, 0:100. Penelitian dilakukan dengan pemberian diet lemak dan kuning telur selama 30 hari pada kelompok perlakukan, kelompok normal mendapatkan pakan tanpa diet lemak. dan dilanjutkan dengan pemberian sediaan uji selama 30 hari. Dosis ekstrak temulawak adalah $225 \mathrm{mg} / \mathrm{kg}$ BB tikus, dosis ekstrak sambung nyawa $150 \mathrm{mg} / \mathrm{kg}$ BB tikus. Kadar trigliserida diukur pada hari ke-0 (baseline), ke-30, dan ke-60

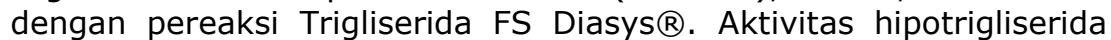
berupa persen perubahan kadar trigliserida dianalisis secara statistik dengan Mann-Whitney taraf kepercayaan $95 \%$. Analisis histopatologi menggunakan sampel aorta jantung. Aktivitas hipotrigliserida kombinasi ekstrak temulawak rendah minyak atsiri dan ekstrak etanolik sambung nyawa tidak berbeda signifikan antara kelompok kombinasi. Kombinasi temulawak:sambung nyawa (75:25) memberikan aktivitas hipotrigliserida tertinggi dengan penurunan kadar trigliserida sebesar 56,77 \%. Kombinasi ekstrak temulawak rendah minyak atsiri dan ekstrak sambung nyawa mampu menghambat terjadinya aterosklerosis.
\end{abstract}

Kata kunci : trigliserida, temulawak, sambung nyawa, aterosklerosis 


\begin{abstract}
Hyperlipidemia is factor affected to coronary hearth disease, allow with increase of serum level cholesterol and tryglycerida. This research is to know effect combination of ethanolic extract of Curcuma xanthorrizha Roxb with low content of volletile oil and ethanolic extract Gynura procumbens (Lour.) on triglyceride level serum and its hyperlipidemia manifestation atherosclerosis. Forty eight male albino rat devide into 8 groups. Positive group receive gemfibrozil, CMC-Na 0,5\% (negatif) and treatment group combination of temulawak and sambung nyawa 100:0, 75:25, 50:50, 25:75, 0:100. Dose of ethanolic extract temulawak is 225 $\mathrm{mg} / \mathrm{kg} B B$ and dose of ethanolic exstrac sambung nyawa 150 Methode of this research by give diet lipid and yolk egg for about 30 day on treatment group except normal group after this give sample test for about 30 day. Trygliceride level serum measure on day 0 (baseline), 30 and 60 with Trigliserida FS Diasys $®$. Hypotrigliceride activity describe into \% of change triglyceride level and analyse with Mann-whitney with level of significane $95 \%$. Histopatology analyze used cardiac aorta. Hypotriglyceride activity combination of extract temulawak and extract sambung nyawa showing no significance difference both combination $(p>0,05)$. Combination of temulawak:sambung nyawa (75:25) give the highest hypotrigliceride activity with decrease on triglyceride level serum for about 56,77\%. Combination both extract effective to avoid atherosclerosis.
\end{abstract}

Key words: triglyceride, temulawak, sambung nyawa, atherosclerosis

\section{PENDAHULUAN}

Penyakit jantung koroner merupakan penyakit jantung akibat perubahan obstruktif pada pembuluh darah koroner yang disebabkan terutama oleh proses aterosklerosis (Martini, 2007). Hiperlipidemia merupakan salah satu faktor yang memicu terjadinya penyakit jantung koroner (Anwar, 2004). Hiperlipidemi ditandai dengan meningginya kadar kolesterol darah (hiperkolesterolemia), dan trigliserida (hipertrigliserida) atau kombinasi keduanya. Tingginya kadar trigliserida merupakan salah satu potensi terjadinya penyakit kardiovaskuler (Jacobs $\mathrm{dkk}$, 2004). Beberapa studi klinik telah mendukung bahwa kadar trigliserida merupakan salah satu faktor risiko independen terhadap penyakit jantung koroner atau Coronary Heart Disease (CHD). Penelitian oleh Manninen (1992) dalam Helsinki Heart Study menunjukkan pasien dengan CHD memiliki kenaikan trigliserida dalam darah dan tingginya rasio LDL/HDL (risiko relatif 3,8) (Manninen cit Chambliss, 2000). Dari gamabaran di atas dapat dikethui bahwa kenaikan kadar trigliserida memainkan peran penting dalam memicu terjadinya resiko penyakit kardiovaskuler.

Minyak atsiri dalam rimpang temulawak (Curcuma xanthorrizha Roxb) memiliki efek penambah nafsu makan sedangkan kurkumin mencegah akumulasi trigliserida pada juga menurunkan trigliserida pada plasma darah (Asai dan Miyazawa, 2001). Pemberian ekstrak rimpang temulawak terpurifikasi dengan dosis $45 \mathrm{mg} / 200 \mathrm{~g} \quad \mathrm{BB}$ mampu menurunkan kadar trigliserida 39,86 \% (Utami, 2006). Sambung nyawa (Gynura procumbens (Lour.) Merr.) mampu menurunkan kadar lipid dalam darah tikus yang diinduksi streptozotosin. Pemberian ekstrak sambung nyawa secara peroral dosis $150 \mathrm{mg} / \mathrm{kg} \mathrm{BB}$ menunjukkan efek optimum terhadap hipoglikemik dan juga mampu menurunkan kadar lipid seperti trigliserida dan kolesterol secara signifikan (Zhang dan Tan, 2000). Perlu dilakukan penelitian untuk mengetahui pengaruh kombinasi kedua ekstrak terhadap kadar 
trigliserida dan manifestasi hiperlipidemi pada aorta jantung.

\section{METODE PENELITIAN}

\section{Bahan}

Rimpang temulawak diperoleh dari Nanggulan, Kulon Progo. sambung nyawa diperoleh dari Kaliurang Timur, Yogyakarta. Gemfibrozil (Phapros). Hewan uji tikus putih jantan galur Wistar, umur 1-2 bulan, bobot 100-150 gram, diperoleh dari Unit Penyediaan Hewan Percobaan (UPHP) UGM. Analisa kadar menggunakan pereakais enzimatik Trigliserida FS Diasys.

Alat

Analisis kromatografi gas Hewlett Pacard 5890 seri II (FMIPA UGM). Alat pemusing (Heraeus-sepatech), analisis kadar trigliserida dalam sampel serum menggunakan Micro Vitalab.

\section{Jalannya Penelitian}

\section{Ektraksi bahan}

Ekstrak temulawak rendah minyak atsiri dibuat dengan destilasi rimpang temulawak selama 15-20 jam menggunakan distilator uap dan air. Kemudian rimpang dikeringkan, diiserbuk dan dilanjutkan dengan maserasi menggunakan etanol $60 \%$. Ekstrak sambung nyawa dibuat dengan maserasi etanol $70 \%$ hingga diperoleh ekstrak kental.

\section{Identifikasi ekstrak}

Identifikasi minyak atsiri ekstrak temulawak dengan kromatografi gas (GC). Analisis kualitatif terhadap 2 sampel yaitu ekstrak etanolik temulawak, dan minyak atsiri hasil destilasi uap air rimpang temulawak. Identifikasi kurkuminoid ekstrak temulawak rendah minyak atsiri dengan metode KLT fase diam silika gel GF254 dan fase gerak kloroform, etanol dan air perbandingan 25:0,96:0,04 (Sudibyo, 1996), deteksi UV 254 dan UV 366. Identifikasi flavonoid ekstrak sambung nyawa dilakukan dengan metode KLT fase diam selulosa mikrokristal dan fase gerak butanol, asam asetat dan air (BAW) perbandingan 4:1:5 deteksi pereaksi semprot uap ammonia (Harborne, 1996).

\section{Penentuan dosis dan kombinasi}

Dosis temulawak $225 \mathrm{mg} / \mathrm{kg}$ BB (Utami, 2006) dan $150 \mathrm{mg} / \mathrm{kg} \mathrm{BB}$ untuk sambung nyawa (Zhang dan Tan, 2000). Dosis kombinasi dilakukan dengan mencampurkan kedua ekstrak sesuai dengan Tabel I.

Tabel I. Penentuan dosis sedian uji

\begin{tabular}{cccccc}
\hline \multicolumn{2}{c}{ Sampel Uji (\%) } & \multicolumn{2}{c}{ Dosis (mg/kg BB) } & $\begin{array}{c}\text { Volume pemberian untuk } \\
\text { tikus 200 } \mathbf{g}(\mathbf{m l})\end{array}$ \\
\hline Temulawak & Sambung nyawa & Temulawak & Sambung nyawa & Temulawak & Sambung nyawa \\
\hline 100 & 0 & 225 & 0 & 1,73 & 0 \\
75 & 25 & 168,75 & 37,5 & 1,29 & 0,43 \\
50 & 50 & 112,5 & 75 & 0,86 & 0,86 \\
25 & 75 & 56,25 & 112,5 & 0,43 & 1,29 \\
0 & 100 & 0 & 150 & 0 & 1,73 \\
\hline
\end{tabular}

Ket : stok suspensi temulawak : $26 \mathrm{mg} / \mathrm{ml}$ stok suspensi sambung nyawa : 17,34 $\mathrm{mg} / \mathrm{ml}$

\section{Perlakuan hewan uji}

Sebanyak 48 hewan uji dibagi dalam 8 kelompok. Kelompok normal, kontrol positif (gemfibrozil), kontrol negatif CMC-Na 0,5\%, dan kelompok kombinasi temulawak sambung nyawa dengan perbandingan 100:0, 75:25, 50:50, 25:75, 0:100. Penelitian dilakukan dengan pemberian diet lemak dan kuning telur selama 30 hari pada kelompok perlakukan, kelompok normal mendapatkan pakan tanpa diet lemak. dan dilanjutkan dengan pemberian sediaan uji selama 30 hari. Dosis ekstrak temulawak adalah 225 $\mathrm{mg} / \mathrm{kg}$ BB tikus, dosis ekstrak sambung nyawa $150 \mathrm{mg} / \mathrm{kg}$ BB tikus. Kadar trigliserida diukur pada hari ke-0 (baseline), ke-30, dan ke-60 dengan pereaksi Trigliserida FS Diasys ${ }^{\circledR}$ menggunakan vitalab micro. 
5. Penentuan purata kenaikan berat badan perhari (PKBP)

Penentuan PKBP dengan penimbangan berat badan hewan uji tikus setiap minggu yaitu dari minggu ke-0 sampai minggu ke-10 selama periode penelitian (60 hari). Penentuan purata kenaikan berat badan perhari dihitung dengan rumus sebagai berikut:

$\mathrm{PKBP}=\underline{\text { berat badan hari ke- } 60-\text { awal }}$ Hari pengamatan

6. Pengamatan gambaran histopatologi

Preparat histopatologi dari aorta jantung diambil pada hari ke-60 dengan pengecatan hematoksilin-eosin. Analisis histopatologi dilakukan di Laboratorium Patologi Fakultas Kedokteran Hewan UGM Yogyakarta.

\section{Analisa Statistik}

Data kadar trigliserida serum diubah dalam bentuk persentase terhadap kadar trigliserida serum pada hari ke-30 dan dianalisis secara statistik dengan metode analisis Mann-Whitney taraf kepercayaan $95 \%$. Nilai PKBP dianalisis secara statistik dengan metode analisis Anova satu arah dengan taraf kepercayaan $95 \%$.

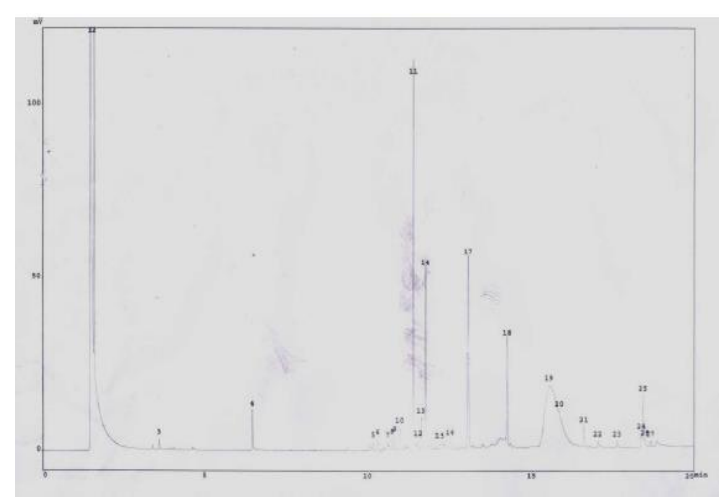

Gambar 1. Kromatogram ekstrak etanolik temulawak (i) dan kromatogram minyak atsiri temulawak (ii)

\section{Aktivitas Hipotrigliserida}

Pemberian diet lemak dan kuning telur selama 30 hari memberikan kenaikan kadar trigliserida yang signifikan $(\mathrm{p}<0,05)$. Pembebanan dilakukan secara kronis dan bukan

\section{HASIL DAN PEMBAHASAN}

1. Identifikasi Kandungan Ekstrak

Kandungan minyak atsiri dalam temulawak memiliki aktivitas yang berlawanan dengan kandungan kurkumin. Oleh karena itu ekstrak temulawak yang dibuat secara teoritis harus bebas dari minyak atsiri. Analisa dengan menggunakan metode $G C$ diketahui bahwa ekstrak etanolik temulawak masih mengandung minyak atsiri (Gambar 1). Hal ini ditandai dengan peak kromatogram pada ekstrak etanolik temulawak memiliki waktu retensi yang mirip dengan peak kromatogram pada minyak atsiri temulawak (Gambar 1 \& Tabel I).

Identifikasi kurkuminoid dengan KLT ekstrak temulawak rendah minyak atsiri ditemukan 2 bercak yang mirip dengan hRf standar yang digunakan yaitu kurkumin dan dimetoksikurkumin. Identifikasi kandungan flavonoid dalam sambung nyawa dengan metode KLT diperoleh 1 bercak dengan fluoresensi kuning orange setelah diberi uap NH3 dan dilihat di bawah sinar UV366. Hal ini menunjukkan adanya kandungan senyawa flavonoid dalam ekstrak etanolik sambung nyawa.

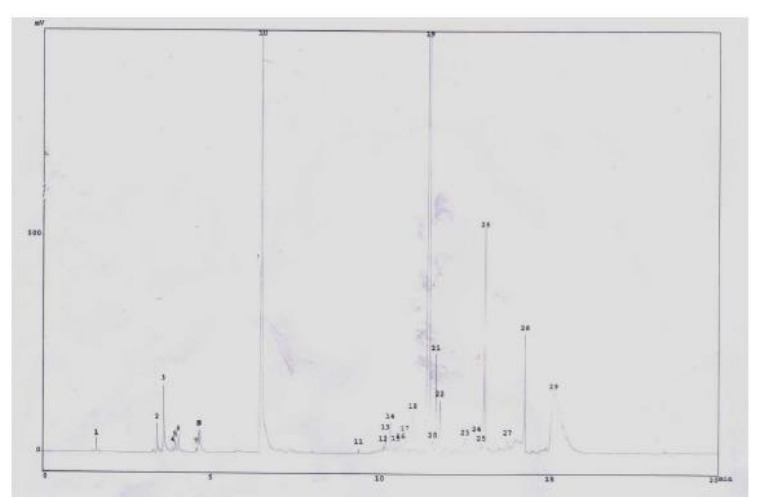

secara akut untuk mendekati keadaan hipertrigliserida yang terjadi pada manusia. Perubahan kadar trigilserida selama periode penelitian dapat dilihat pada Tabel II. 
Pengaruh Kombinasi Ekstrak Etanolik Temulawak Rendah Minyak Atsiri dan Ekstrak Etanolik Sambung Nyawa Terhadap Kadar Trigliserida

Tabel I. Data kromatografi gas ekstrak etanolik temulawak dan minyak atsiri temulawak

\begin{tabular}{cccccc}
\hline \multicolumn{2}{c}{$\begin{array}{c}\text { Minyak atsiri temulawak } \\
\text { Waktu retensi } \\
\text { (detik) }\end{array}$} & Luas area & No Peak & $\begin{array}{c}\text { Ekstrak etanolik temulawak } \\
\text { Waktu retensi } \\
\text { (detik) }\end{array}$ & Luas area \\
\hline 14 & 10,317 & 143109 & 6 & 10,319 & 5539 \\
19 & 11,475 & 4837741 & 11 & 11.407 & 212496 \\
26 & 13,085 & 1284645 & 17 & 13,059 & 111026 \\
28 & 14,270 & 590984 & 18 & 14,252 & 59279 \\
\hline
\end{tabular}

Pemberian kombinasi ekstrak dilakukan selama 30 hari dari hari ke-31 sampai hari ke-60. Kombinasi ekstrak mampu memberikan penurunan kadar trigliserida sebesar 35,51-56,77\% (Gambar 2). Naiknya \% kombinasi ekstrak etanolik temulawak rendah minyak atsiri dan turunnya \% kombinasi sambung nyawa maka aktivitas hipotrigliserida (penurunan kadar trigliserida) akan meningkat. Sama seperti pada kelompok kombinasi, gemfibrozil juga mampu menurunkan kadar trigliserida. Kelompok II kombinasi temulawak:sambung nyawa (75:25) mampu memberikan penurunan kadar trigliserida tertinggi diantara kelompok kombinasi yaitu 56,77 \%. Analisis statistik dengan Mann-Whitney menunjukkan aktivitas hipotrigliserida pada kelompok kombinasi ini berbeda signifikan dengan kontrol negative dan gemfibrozil ( $\mathrm{p}<0,05)$. Aktivitas hipotrigliserida antara kombinasi tidak berbeda signifikan $(p>0,05)$.

Tabel II. Perubahan kadar trigliserida

\begin{tabular}{|c|c|c|c|c|c|}
\hline \multirow{2}{*}{ Kelompok } & \multicolumn{2}{|c|}{ Sampel Uji (\%) } & \multicolumn{3}{|c|}{$\begin{array}{c}\text { Kadar trigliserida hari ke- (rata-rata } \pm \square \text { SE) } \\
\text { dalam } \mathrm{mg} / \mathrm{dL}\end{array}$} \\
\hline & Temulawak & $\begin{array}{c}\text { Sambung } \\
\text { nyawa }\end{array}$ & 0 & 30 & 60 \\
\hline $\mathrm{I}$ & 100 & 0 & $71,00 \pm 4,77$ & $159,40 \pm \square 22,46$ & $88,20 \pm 15,83$ \\
\hline II & 75 & 25 & $78,80 \pm \square 2,74$ & $247,50 \pm \square 21,59$ & $105,20 \pm 13,3$ \\
\hline III & 50 & 50 & $68,20 \pm 6,90$ & $164,60 \pm \square 19,2$ & $84,60 \pm 9,12$ \\
\hline IV & 25 & 75 & $65,30 \pm \square 4,54$ & $157,00 \pm \square 17,49$ & $92,80 \pm 6,96$ \\
\hline $\mathrm{V}$ & 0 & 100 & $62,17 \pm 2,69$ & $168,20 \pm \square 18,92$ & $107,60 \pm \square 12,12$ \\
\hline$K-$ & \multicolumn{2}{|c|}{ Kontrol negatif } & $68,00 \pm \square 5,16$ & $161,50 \pm \square 15,34$ & $202,50 \pm \square 20,5$ \\
\hline $\mathrm{K}+$ & \multicolumn{2}{|c|}{$\begin{array}{c}\text { Gemfibrozil } \\
\text { dosis } 108 \mathrm{mg} / \mathrm{kg} \mathrm{BB}\end{array}$} & $83,50 \pm \square 7,39$ & $176,70 \pm \square 16,96$ & $116,33 \pm \square 4,47$ \\
\hline $\mathrm{N}$ & \multicolumn{2}{|c|}{ Normal } & $71,17 \pm 5,48$ & $72,83 \pm \square 10,49$ & $96,67 \pm \square 10,81$ \\
\hline
\end{tabular}

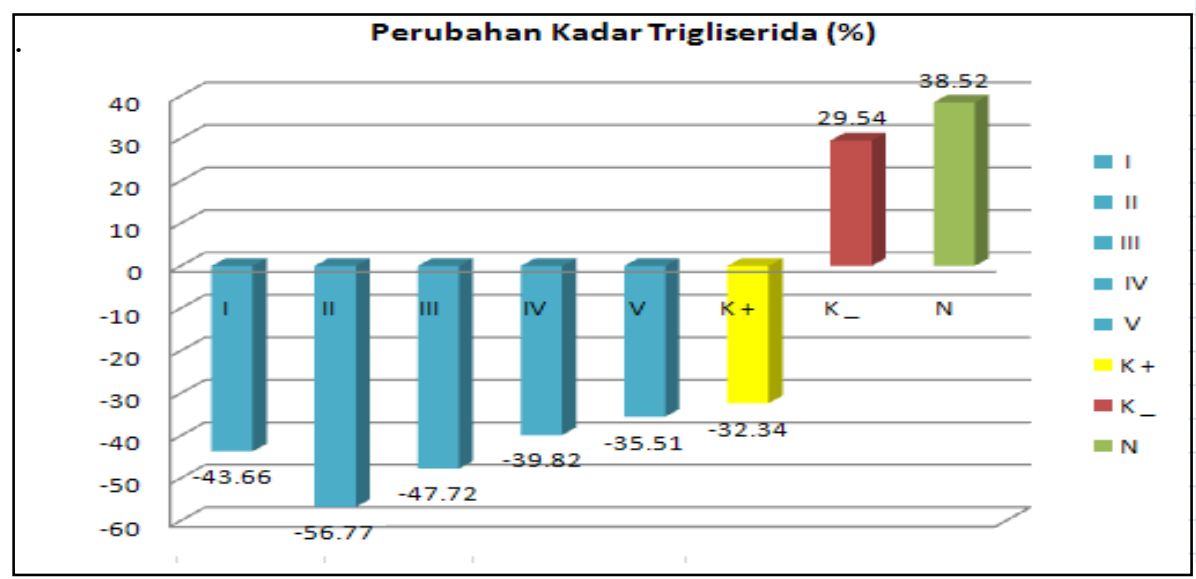

Gambar 2. Perubahan kadar trigliserida setelah pemberian sediaan uji. 



\section{Purata Kenaikan Berat Badan (PKBP)}

Penentuan Purata Kenaikan Berat Badan Tikus Perhari (PKBP) dilakukan untuk mengetahui apakah pemberian ekstrak etanolik temulawak rendah minyak atsiri dan ekstrak etanolik sambung nyawa memiliki pengaruh terhadap nafsu makan. Manifestasi dari adanya nafsu makan yaitu diketahui dengan peningkatan berat badan tikus. Adanya manifestasi dari nafsu makan mengindikasikan bahwa sediaan uji yang digunakan memiliki aktivitas yang berlawanan sebagai agen hipolipidemi. Data PKBP hewan uji dapat dilihat dalam Tabel III. Kedua ekstrak yang digunakan tunggal maupun kombinasi tidak memiliki pengaruh terhadap kenaikan berat badan dilihat dari parameter $\operatorname{PKBP}(\mathrm{p}>0,05)$.

Tabel III. Data PKBP hewan uji selama periode penelitian

\begin{tabular}{ccc}
\hline \multicolumn{3}{c}{ Sampel Uji (\%) } \\
Temulawak & $\begin{array}{c}\text { Sambung } \\
\text { nyawa }\end{array}$ \\
\hline 100 & 0 & $2,14 \pm 0,07$ \\
75 & 25 & $2,20 \pm 0,07$ \\
50 & 50 & $2,31 \pm 0,20$ \\
25 & 75 & $2,33 \pm 0,16$ \\
0 & 100 & $2,32 \pm 1,04$ \\
Kontrol negatif & $2,45 \pm 0,23$ \\
Gemfibrozil & $1,95 \pm 0,12$ \\
dosis 108 mg/kg BB & $1,85 \pm 0,06$ \\
\hline \multicolumn{2}{c}{ Normal } &
\end{tabular}

\section{Analisa Histopatologi Aorta Jantung}

Analisis histopatologi untuk mengetahui pengaruh kombinasi ekstrak terhadap manifestasi hiperlipidemi yaitu aterosklerosis, Aterosklerosis terjadi akibat adanya partikel LDL dalam tunika intima yang mengalami proses osidasi yang akhirnya terakumulasi membentuk plak lemak (Anwar, 2004).

Terlihat penebalan pada tunika intima pada kelompok kontrol negative menunjukkan adanya plak ateroma (Gambar 3). Pemberian kombinasi temulawak:sambung nyawa (100:0); (75:25), dan (50:50) mampu menghambat aterosklerosis. Kombinasi temulawak:sambung nyawa (25:75) dan (0:100) terlihat adanya penebalan pada daerah tunika intima. Semakin tinggi persen kombinasi ekstrak temulawak rendah minyak atsiri terjadinya aterosklerosis dapat diminimalkan, semakin tinggi persen kombinasi ekstrak etanolik sambung nyawa aktivitas penghambatan aterosklerosis akan menurun.

Mekanisme hipotrigliserida kurkumin melalui induksi intra dan ekstraseluler katabolisme asam lemak meliputi induksi $\beta$ oksidasi asam lemak dan hidrolisis trigliserida. Hidrolisis trigliserida dipercepat karena metabolit dari kurkumin berperan sebagai ligan yang mengaktivkan PPAR. Pemberian kurkumin secara peroral diabsorbsi dan ditemukan dalam darah konjugasi dengan asam glukoronat dan asam sulfat. Bentuk konjugasi inilah yang diprediksi berperan sebagai ligan yang mengaktifkan PPAR (Asai dan Miyazawa, 2001). Kurkumin bertindak sebagai antioksidan yang mencegah terjadinya oksidasi LDL. 
Menurunnya LDL teroksidasi kemungkinan terjadinya adesi monosit dan terbentuknya foam cell yang mengarah pada plak ateroma dapat diminimalkan. Kurkumin juga dapat meningkatkan ekspresi LDL reseptor (Fan dkk, 2006). Kandungan flavonoid (7,3`,4` trihidroksiflavon), glikosida kuersetin dalam sambung

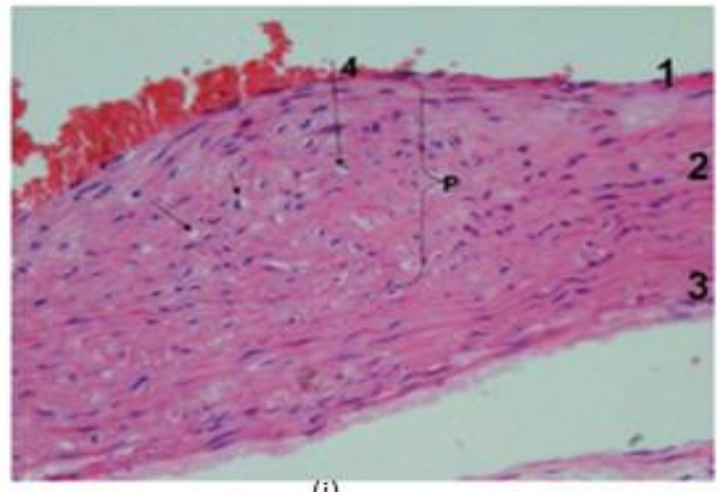

(i)

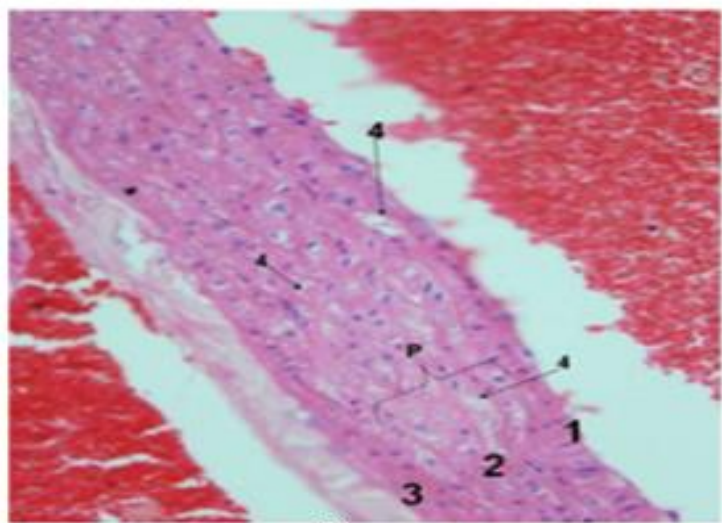

(ii) nyawa diduga bertanggung jawab terhadap aktivitas hipolipidemi. Kuersetin menstimulasi liver microsomal 7a-hydroxylation yang mengkonversi kolesterol menjadi bile acids (Juzwiak $\mathrm{dkk}, 2005)$. Kuersetin menghambat oksidasi LDL, oksidasi LDL mengawali terjadinya atherosklerosis (Lakhanpal dan Rai, 2008).

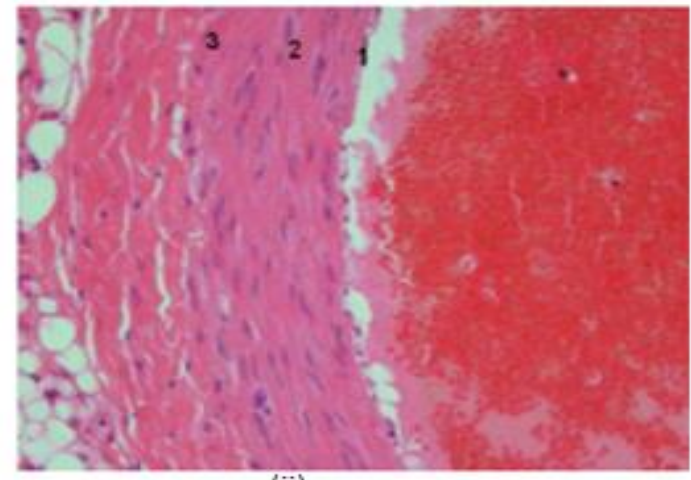

(ii)

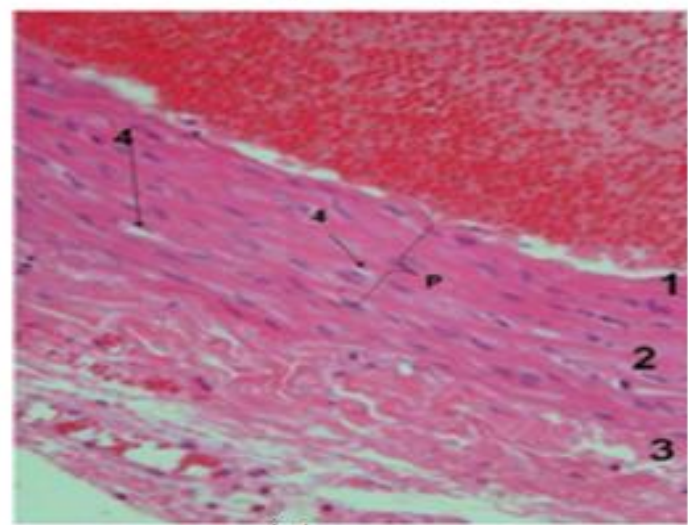

(iv)

Gambar 3. Histopatologi aorta kontrol negative, (i), kelompok normal dan kelompok temulawak:sambung nyawa 75:25 (ii), Kelompok temulawak:sambung nyawa 25:75 (iii) dan kelompok temulawak:sambung nyawa 0:100 (iv) (perbesaran 10x40). Ket: 1 . t unika intima 2. tunika media 3. tunika adventitia 4 . vakuolisasi. $P=$ Penebalan

\section{KESIMPULAN}

Kombinasi ekstrak temulawak rendah minyak atsiri dan ekstrak sambung nyawa mampu menurunkan kadar trigliserida. Semakin tinggi persen kombinasi ekstrak temulawak rendah minyak atsiri dan semakin rendah ekstrak sambung nyawa maka risiko aterosklerosis dapat diminimalkan. Aktivitas hipotrigliserida tertinggi yaitu kombinasi temulawak:sambung nyawa dengan penurunan kadar trigliserida sebesar $56,77 \%$.

\section{DAFTAR PUSTAKA}

Anwar, T.B., 2004, Dislipidemia Sebagai Faktor Resiko Penyakit Jantung Koroner, e-USU respisitory, 1-10, Universitas Sumatera Utara.

Asai, A. and Miyazawa, T., 2001, Dietary Curcuminoids Prevent High Fat Diet-Induced Lipid 
Accumulation in Rat Liver and Epididymal Adipose Tissue, Journal Nutrition., 131(11), 29322935.

Fan, C., Wo, X., Qian, Y., and Yin, J., 2006, Effect of Curcumin on The Expression of LDL Receptor in Mouse Macrophages, Journal of Ethnopharmacology., 105:251-254

Harborne, J.B., 1996, Metode Fitokimia, Terbitan kedua, 58-94, Penerbit ITB, Bandung.

Jacobs ,B., Egert, S., and Kratz, M., 2004, Individual Serum Triglyceride Responses to High-Fat and LowFat Diets Differ in Men with Modest and Severe Hypertriglyceridemia, The American Society for Nutritional Sciences J, 134:1400-1405.

Juzwiak, S., Wojcicki, J., Mokrzycki, K., and Marchleswicz, M., 2005, Effect of Quercetin on Experimental Hyperlipidemia and Atherosclerosis in Rabbits, Pharmocological reports, 57:604-609.

Lakhanpal, P. and Rai, D.K., 2008, Role Of Quercetin In Cardiovascular
Diseases, Journal of Medical Update, 3(1):31-49.

Martini, 2007, Hindari Penyakit Jantung

Koroner,

http://www.humanmedicine.net, 20 November 2007.

Sudibyo, R.S., 1996, Penentuan Kandungan Kurkumin secara Kromatografi Lapis Tipis Densitometri, Buletin ISFI, Vol.2 No.4, 11-12.

Utami, V.V.F.R., 2006, Pengaruh Pemberian Ekstrak Temulawak (Crcuma xanthorrbiza roxb.) Terpurifikasi terhadap Kadar Trigliserida pada Tikus Putih Jantan Galur Wistar yang Diberi Pakan Diet Lemak Tinggi dan Kolesterol, Skripsi, Fakultas Farmasi Universitas Gadjah Mada Yogyakarta.

Zhang, dan Tan, 2000, Effects of an Ethanolic Extract of Gynura procumbens on Serum, Glucose, Cholesterol and Triglyceride Levels in Normal and Streptozotocin-Induced Diabetic Rats, Singapore Med J. 41(1):9-13. 